University of Nebraska - Lincoln

DigitalCommons@University of Nebraska - Lincoln

1973

\title{
Changes in Polysomes of black locust seedlings during dehydration-rehydration cycles
}

James R. Brandle

University of Nebraska - Lincoln, jbrandle1@unl.edu

P.D. Schnare

T.M. Hinckley

G.N. Brown

Follow this and additional works at: https://digitalcommons.unl.edu/natrespapers

Part of the Natural Resources and Conservation Commons, Natural Resources Management and Policy Commons, and the Other Environmental Sciences Commons

Brandle, James R.; Schnare, P.D.; Hinckley, T.M.; and Brown, G.N., "Changes in Polysomes of black locust seedlings during dehydration-rehydration cycles" (1973). Papers in Natural Resources. 1089.

https://digitalcommons.unl.edu/natrespapers/1089

This Article is brought to you for free and open access by the Natural Resources, School of at DigitalCommons@University of Nebraska - Lincoln. It has been accepted for inclusion in Papers in Natural Resources by an authorized administrator of DigitalCommons@University of Nebraska - Lincoln. 


\title{
Changes in Polysomes of Black Locust Seedlings during Dehydration-Rehydration Cycles
}

\author{
By \\ JAMES R. BRANDLE, PAUL D. SCHNARE, THOMAS M. HINCKLEY, \\ and GREGORY N. BROWN \\ School of Forestry, University of Missouri, Columbia, Missouri 65201 \\ (Received July 12, 1973)
}

\begin{abstract}
Net assimilation, dark respiration and xylem pressure potential were followed through dehydration-rehydration cycles in black locust seedlings (Robinia pseudoacacia L.). Sucrose gradient profiles indicated the retention of polysomes during stress. RNase activity declined during dehydration but returned to pre-stress levels upon irrigation. Comparisons of black locust and corn polysomes during water stress are made.
\end{abstract}

\section{Introduction}

Literature in water stress physiology often generalizes the response of one particular metabolic system of a physically measured water stress but frequently overlooks likely differences between species, stages of development, previous conditioning of plants or intensity and duration of stress. The study presented herein measured xylem pressure potential as a physical indication of water stress supplemented by corresponding measurements of net assimilation, dark respiration, ribosomal profiles and RNase activity as biological indicators of water stress.

The effect of water stress on ribosomal patterns and protein synthesis has been followed under many conditions. Dramatic changes have been reported in 2.75 dayold corn seedlings (Hsiao 1970), in 14 day-old corn seedlings (Genkel et al. 1967), in 2 day-old maize root tips (Nir et al. 1970) and in 5 day-old bean seedlings (Satarova and Tvorus 1971). However, in all these cases the tissues being considered were relatively young, a stage of development when drought resistance is at its lowest (Levitt 1972, Chen 1968). RNase activity also responds to different degrees of water stress (Dove 1967, Kessler 1959, Marin and Vieira Da Silva 1972) and during various stages of development (Kessler and Engelberg 1962).

The objectives of this study were to describe the effect of dehydration-rehydration cycles on xylem pressure potential, net assimilation, dark respiration, ratio of polysomes to monomers and RNase activity in black locust seedlings and to make comparisons between polysome ratios of black locust, a woody, drought tolerant species, and those of corn, a less tolerant species.

Abbreviations: $\mathrm{RW} C$, relative water content; $\psi_{\mathrm{p}}$, xylem pressure potential.

\section{Material and Methods}

Black locust (Robinia pseudoacacia L.) seedlings were grown for 5 months in vermiculite under a light intensity of $0.698 \mathrm{~W} / \mathrm{m}^{2}$ at $25^{\circ} \mathrm{C}$, and a relative humidity of $40 \%$. Flats of seedlings were transferred to a growth chamber with an air temperature of $25^{\circ} \mathrm{C}$, a light intensity of $2.65 \mathrm{~W} / \mathrm{m}^{2}$, a relative humidity of $35 \%$ and a photoperiod of 16 hours for a 5 -day preconditioning period.

Following the preconditioning period, duplicate xylem pressure potential $\left(\psi_{p}\right)$ measurements were made at 0.5 hours before and 4.5 hours into the light period using a pressure chamber (Scholander et al. 1965, Boyer and Ghorashy 1971). Duplicate relative water content (RWC) determinations were made. These initial readings were designated as Day 1 and additional readings were taken at subsequent 24-hour intervals. At 4.5 hours into each photoperiod, samples of leaf tissue were taken for polysome preparations. Water was withheld and sampling was continuous until visible wilting occurred in the dark. At this point, Day 6 or 7, xylem pressure potential was approximately -25 bars. On this day a final pre-irrigation sample was taken at 4.5 hours into the light period and the soil was irrigated to field capacity. Xylem pressure potential was measured every 0.5 hours following irrigation for 12 hours at which time the pre- 
irrigation schedule was resumed. Polysome samples were taken at $0.5,4.5,24$, and 48 hours following irrigation. Carbon dioxide exchange was monitored continuously using a ventilated cuvette and a Beckman 315B infrared gas analyzer. At the end of each experiment, cuvette foliage was harvested, leaf area determined, oven dried at $72^{\circ} \mathrm{C}$ for 24 hours and weighed. This complete dehydration-rehydration cycle was repeated twice.

At each polysome sampling time, 1.5 grams (fresh weight) of leaf tissue were excised into $10 \mathrm{ml}$ of $0.3 \mathrm{M}$ Tris, $\mathrm{pH} 7.8,0.01 \mathrm{M} \mathrm{MgCl}, 0.06 \mathrm{M} \mathrm{KCl}, 5 \%$ RNasefree sucrose $(\mathrm{w} / \mathrm{v})$ and $2.5 \%$ Triton $\mathrm{X}-100(\mathrm{w} / \mathrm{v})$. Tissue was homogenized at $4^{\circ} \mathrm{C}$ for two 10 -s bursts separated by $10 \mathrm{~s}$ to prevent local heating of the homogenate. Homogenates were strained through cheesecloth and centrifuged at $7000 \times \mathrm{g}$ for $10 \mathrm{~min}$ at $0^{\circ} \mathrm{C}$. Supernatant fractions $(1.1 \mathrm{ml})$ were layered on linear sucrose gradients $(37 \mathrm{ml})$ and centrifuged at $105,000 \times \mathrm{g}$ for 15 hours at $4^{\circ} \mathrm{C}$. Sucrose gradients were prepared using $30 \%$ to $60 \%$ RNase-free sucrose $(\mathrm{w} / \mathrm{v})$ in $0.3 \mathrm{M}$ Tris, $\mathrm{pH} 7.8,0.01 \mathrm{M} \mathrm{MgCl}_{2}$ and $0.06 \mathrm{M} \mathrm{KCl}$. Gradients were fractionated and scanned using an ISCO Gradient Fractionator System at a wavelength of $254 \mathrm{~nm}$. This procedure is a modification of that used by Brown (1972).

Percent polysomes was determined by means of a planimeter taking the area under the polysome region divided by the combined area under the monomer and polysome regions.

Ribonuclease preparation and activity were determined by a modification of the procedures of Tuve and Anfinsen (1960) with the following alterations: (a) tissue was homogenized in $0.2 M$ acetate buffer in a Virtis homogenizer, (b) homogenates were immediately centrifuged for $10 \mathrm{~min}$ at $13,000 \times \mathrm{g}$ and (c) supernatant solutions were filtered through $5 \mathrm{~cm}$ columns of Hyflo Super Cel under vacuum (Brown and Bixby 1973).

In order to examine the possibility of inducing drought hardiness during the 6 to 7 day dehydration period, 5 month-old black locust seedlings were dehydrated from -7 bars to -25 bars in 3 hours by removing plants from the soil. Recovery was initiated by submerging the roots in distilled water and by cutting the roots at the root collar.

\section{Results and Discussion}

Changes in net assimilation and dark respiration with changes in xylem pressure potential $\left(\psi_{p}\right)$ are plotted in Figure $1 \mathrm{~A}$. As $\psi_{\mathrm{p}}$ decreased, these two metabolic processes decreased and approached zero, thereby quantifying one aspect of black locust's sensitivity to water stress. These decreases in net assimilation and dark respiration probably resulted in reduced energy pools and, hence, less protein synthesis.

Figure 2 illustrates the response of ribosomal profiles to water stress and subsequent recovery. Day 2 repre- sents the unstressed plant $\left(\psi_{p}^{\prime}=-11.5\right.$ bars, RWC = $=79.2 \%$ with $42.7 \%$ polysomes. Day 7 represents the fully stressed plants $\left(\psi_{\mathrm{p}}=-23.2\right.$ bars, RWC $=69.8 \%$ \% with $32.5 \%$ polysomes. Day 8 represents the recovered plant 24 hours following irrigation $\left(\psi_{\mathrm{p}}=-9.2\right.$ bars, $\mathrm{RWC}=80.1 \%$ ) with $48.9 \%$ polysomes.

Figure $1 B$ plots percent polysomes against $\psi \mathrm{p}$ for the black locust reported herein and for Hsiao's data on corn as a comparison. The black locust data indicated a $1 \%$ change in percent polysomes/bar while those of corn indicated a $6 \%$ change in percent polysomes/bar. Consequently a much greater retention of polysomes appeared in black locust seedlings than in corn seedlings during stress, however, retention of polysomes does not necessarily insure retention of active protein synthesis (Hsiao 1970, Burka 1972, Schwarz and Landau 1972). These differences in polysome responses to drought stress may be related to inherent hardiness differences between the two species. Black locust is a drought hardy pioneer species frequently found on dry sites, and the seedlings used in this study represented a mature stage of development comparable to field grown seedlings during the first growing season. In contrast, Hsiao's corn seedlings were young, etiolated seedlings possessing relatively less drought hardiness.

Growth conditions prior to induction of stress may have provided some preconditioning of the black locust seedlings. The length of the dehydration period itself may also have provided some preconditioning or drought hardiness. However, results of the short term study indicated changes in the percent polysomes of the same magnitude as those reported for the longer dehydration period (Figure $1 B$ ).

The concept of species difference relative to drought hardiness is further emphasized in work by Bewley (1972). Working with a moss, a relatively hardy plant adapted to dry sites, he showed only a $16 \%$ loss in polysomes with a loss in relative water content of $80 \%$, followed by complete recovery upon rehydration. Schwarz and Landau (1972), working with Escherichia coli, showed that polysome integrity is not affected by hydrostatic pressures up to 689 bars.

Polysome retention may be related to RNase activity (Kessler 1959). Figure 3 represents RNase changes in black locust during the dehydration-rehydration cycle. Day "0" represents the day of irrigation. This loss of RNase activity in black locust during stress could account for the relative retention of polysomes in the probable absence of active protein synthesis. However, during rehydration, both RNase activity and percent polysomes increased indicating RNase not to be the only factor regulating polysome retention. Bewley (1972) used diethyl pyrocarbonate (DEP) to eliminate the possibility of RNase activity during ribosomal preparation from mosses and obtained the same results as without 
irrigation schedule was resumed. Polysome samples were taken at $0.5,4.5,24$, and 48 hours following irrigation. Carbon dioxide exchange was monitored continuously using a ventilated cuvette and a Beckman 315B infrared gas analyzer. At the end of each experiment, cuvette foliage was harvested, leaf area determined, oven dried at $72^{\circ} \mathrm{C}$ for 24 hours and weighed. This complete dehydration-rehydration cycle was repeated twice.

At each polysome sampling time, 1.5 grams (fresh weight) of leaf tissue were excised into $10 \mathrm{ml}$ of $0.3 \mathrm{M}$ Tris, pH 7.8, $0.01 \mathrm{M} \mathrm{MgCl}_{2}, 0.06 \mathrm{M} \mathrm{KCl,} 5 \%$ RNasefree sucrose $(w / v)$ and $2.5 \%$ Triton $X-100(w / v)$. Tissue was homogenized at $4^{\circ} \mathrm{C}$ for two 10 -s bursts separated by $10 \mathrm{~s}$ to prevent local heating of the homogenate. Homogenates were strained through cheesecloth and centrifuged at $7000 \times \mathrm{g}$ for $10 \mathrm{~min}$ at $0^{\circ} \mathrm{C}$. Supernatant fractions $(1.1 \mathrm{ml})$ were layered on linear sucrose gradients $(37 \mathrm{ml})$ and centrifuged at $105,000 \times \mathrm{g}$ for 15 hours at $4^{\circ} \mathrm{C}$. Sucrose gradients were prepared using $30 \%$ to $60 \%$ RNase-free sucrose (w/v) in $0.3 \mathrm{M}$ Tris, pH 7.8, 0.01 $\mathrm{M} \mathrm{MgCl}_{2}$ and $0.06 \mathrm{M} \mathrm{KCl}$. Gradients were fractionated and scanned using an ISCO Gradient Fractionator System at a wavelength of $254 \mathrm{~nm}$. This procedure is a modification of that used by Brown (1972).

Percent polysomes was determined by means of a planimeter taking the area under the polysome region divided by the combined area under the monomer and polysome regions.

Ribonuclease preparation and activity were determined by a modification of the procedures of Tuve and Anfinsen (1960) with the following alterations: (a) tissue was homogenized in $0.2 M$ acetate buffer in a Virtis homogenizer, (b) homogenates were immediately centrifuged for $10 \mathrm{~min}$ at $13,000 \times \mathrm{g}$ and (c) supernatant solutions were filtered through $5 \mathrm{~cm}$ columns of Hyflo Super Cel under vacuum (Brown and Bixby 1973).

In order to examine the possibility of inducing drought hardiness during the 6 to 7 day dehydration period, 5 month-old black locust seedlings were dehydrated from -7 bars to -25 bars in 3 hours by removing plants from the soil. Recovery was initiated by submerging the roots in distilled water and by cutting the roots at the root collar.

\section{Results and Discussion}

Changes in net assimilation and dark respiration with changes in xylem pressure potential $\left(\psi_{\mathrm{p}}\right)$ are plotted in Figure $1 \mathrm{~A}$. As $\psi_{p}$ decreased, these two metabolic processes decreased and approached zero, thereby quantifying one aspect of black locust's sensitivity to water stress. These decreases in net assimilation and dark respiration probably resulted in reduced energy pools and, hence, less protein synthesis.

Figure 2 illustrates the response of ribosomal profiles to water stress and subsequent recovery. Day 2 repre- sents the unstressed plant $\left(\psi_{\mathrm{p}}=-11.5\right.$ bars, RWC = $=79.2 \%$ ) with $42.7 \%$ polysomes. Day 7 represents the fully stressed plants $\left(\psi_{\mathrm{p}}=-23.2\right.$ bars, RWC $\left.=69.8 \%\right)$ with $32.5 \%$ polysomes. Day 8 represents the recovered plant 24 hours following irrigation $\left(\psi_{p}=-9.2\right.$ bars, RWC $=80.1 \%$ ) with $48.9 \%$ polysomes.

Figure $1 B$ plots percent polysomes against $\psi \mathrm{p}$ for the black locust reported herein and for Hsiao's data on corn as a comparison. The black locust data indicated a $1 \%$ change in percent polysomes/bar while those of corn indicated a $6 \%$ change in percent polysomes/bar. Consequently a much greater retention of polysomes appeared in black locust seedlings than in corn seedlings during stress, however, retention of polysomes does not necessarily insure retention of active protein synthesis (Hsiao 1970, Burka 1972, Schwarz and Landau 1972). These differences in polysome responses to drought stress may be related to inherent hardiness differences between the two species. Black locust is a drought hardy pioneer species frequently found on dry sites, and the seedlings used in this study represented a mature stage of development comparable to field grown seedlings during the first growing season. In contrast, Hsiao's corn seedlings were young, etiolated seedlings possessing relatively less drought hardiness.

Growth conditions prior to induction of stress may have provided some preconditioning of the black locust seedlings. The length of the dehydration period itself may also have provided some preconditioning or drought hardiness. However, results of the short term study indicated changes in the percent polysomes of the same magnitude as those reported for the longer dehydration period (Figure $1 B$ ).

The concept of species difference relative to drought hardiness is further emphasized in work by Bewley (1972). Working with a moss, a relatively hardy plant adapted to dry sites, he showed only a $16 \%$ loss in polysomes with a loss in relative water content of $80 \%$, followed by complete recovery upon rehydration. Schwarz and Landau (1972), working with Escherichia coli, showed that polysome integrity is not affected by hydrostatic pressures up to 689 bars.

Polysome retention may be related to RNase activity (Kessler 1959). Figure 3 represents RNase changes in black locust during the dehydration-rehydration cycle. Day " 0 " represents the day of irrigation. This loss of RNase activity in black locust during stress could account for the relative retention of polysomes in the probable absence of active protein synthesis. However, during rehydration, both RNase activity and percent polysomes increased indicating RNase not to be the only factor regulating polysome retention. Bewley (1972) used diethyl pyrocarbonate (DEP) to eliminate the possibility of RNase activity during ribosomal preparation from mosses and obtained the same results as without 


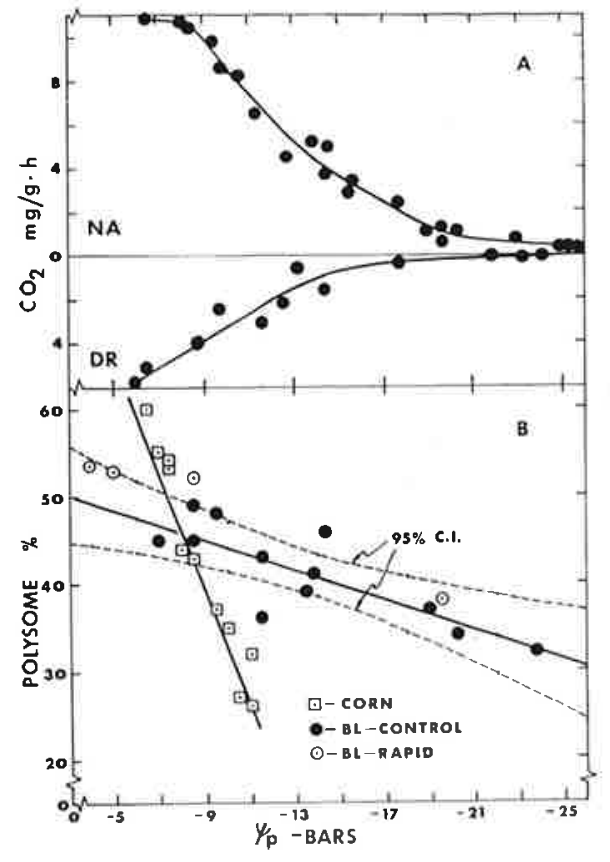

Figure 1.

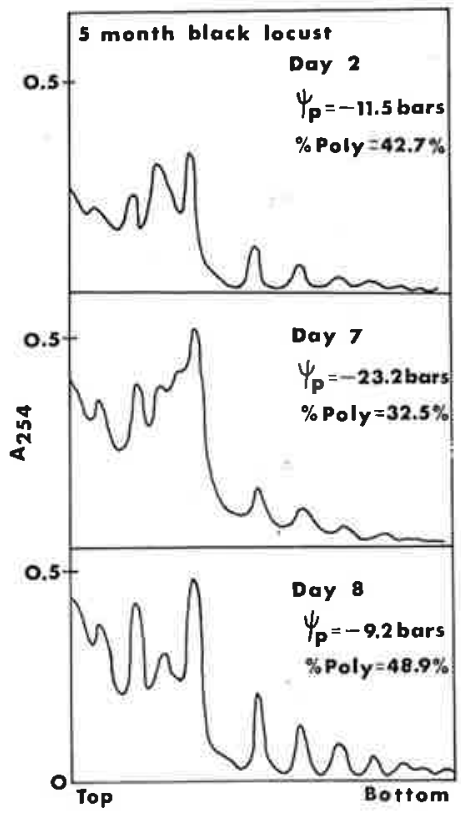

Figure 2.

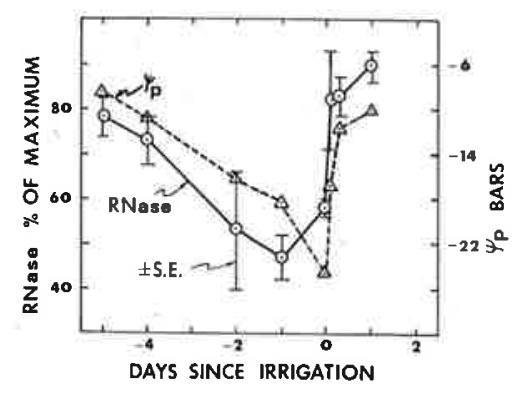

Figure 3.

Figure 1. A. Effect of xylem pressure potential $\left(\psi_{\mathrm{p}}\right)$ on net assimilation (NA) and dark respiration (DR) in black locust. B. Effect of $\psi_{p}$ on the percentage of polysomes in black locust and corn (Hsiao 1970). For black locust (BL), $\%$ polysomes $=52.81+$ $+0.85\left(\psi_{p}\right)$ with $\mathrm{R}^{2}=0.64$ while for corn $\%$ polysomes $=98.64+6.57\left(\psi_{p}\right)$ with $\mathrm{R}^{2}=0.95$. The open circles are data taken during rapid dehydrationrehydration. The confidence interval (C.I.) was determined according to Snedecor and Cochran (1956).

Figure 2. Changes in ribosomal profiles during a debydration-rebydration of black locust seedlings. Day 2, unstressed; Day 7 , fully stressed; Day 8, recovered.

Figure 3. Relationship between RNase activity, water stress and days since irrigation.

DEP, suggesting the lack of polysome relationship to RNase activity.

In conclusion, black locust seedlings, a drought hardy species, do not show the dratstic loss of polysomes (Hsiao 1970, Satarova and Tvorus 1971) nor the drastic increase in RNase activity (Dove 1967) during drought stress of less hardy plants. It seems plausible that the mechanism of retention of polysomes in stress resistant higher plants may be similar to that seen in stressresistant moss (Bewley 1972, 1973).

The data reported herein, when compared with other studies on water stress and polysome retention suggest that broad generalizations regarding drought stress should not be drawn from a limited number of species at limited stages of development with different past histories of environmental conditions.

Contribution from the Missouri Agricultural Experiment Station. Journal Series Number 6661.

\section{References}

Bewley, J. D. 1972. The conservation of polysomes in the moss Tortula ruralis during total desiccation. - J. Exp. Bot. 23: 692-698.

- 1973. Desiccation and protein synthesis in the moss Tortula ruralis. - Can. J. Bot. 51: 203-206.
Boyer, J. S. \& Ghorashy, S. R. 1971. Rapid field measurement of leaf water potential on soybean. - Agron. J. 63: 344-345.

Brown, G. N. 1972. Changes in ribosomal patterns and a related membrane fraction during induction of cold hardiness in mimosa epicotyl tissues. - Plant Cell Physiol. 13: 345-351.

— \& Bixby, J. A. 1973. Ribonuclease activity during induction of cold hardiness in Mimosa epicotyl and hypocotyl tissues. - Cryobiology 10:152-156.

Burka, E. R. 1972. The relationship between reticulocyte polyribosome structure and function. - Biochim. Biophys. Acta 259: 117-126.

Chen, D., Sarid, S. \& Katchalski, E. 1968. The role of water stress in the inactivation of messenger RNA of germinating wheat embryos. - Biochemistry 61: 1378-1383.

Dove, L. D. 1967. Ribonuclease activity of stressed tomato leaflets. - Plant Physiol. 42: 1176-1178.

Genkel, P. A., Satarova, N. A. \& Tvorus, E. K. 1967. Effects of drought on protein synthesis and the state of ribosomes in plants. - Sov. Plant Physiol. 14: 754-762.

Hsiao, 'T. C. 1970. Rapid changes in levels of polyribosomes in Zea mays in response to water stress. - Plant Physiol. 46: 281-286.

Kessler, B. 1959. Nucleic acids as factors in drought resistance of higher plants. - Rec. Adv. Bot. 2: 1153-1160.

- \& Engelberg, N. 1962. Ribonucleic acid and ribonuclease activity in developing leaves. - Biochim. Biophys. Acta $55: 70-82$.

Levitt, J. 1972. Responses of Plants to Environmental Stresses. - Academic Press, New York. 
Marin, B. \& Vieira Da Silva, J. 1972. Influence de la carence hydrique sur la repartition cellulaire de l'acide ribonucléique foliaire chez le contonnier. - Physiol. Plant. 27: $150-155$.

Nir, I., Poljakoff-Mayber, A. \& Klein, S. 1970. The effect of water stress on the polysome population and the ability to incorporate amino acids in maize root tips. - Isr. J. Bot. 19: 451-462.

Satarova, N. A. \& Tvorus, E. K. 1971. Changes of in vitro functional activity of ribosomes from bean seedlings exposed to drying. - Sov. Plant Physiol. 18: 448-454.
Scholander, P. F., Hammel, H. T., Bradstreet, E. D. \& Hemmingsen, E. A. 1965. Sap pressure in vascular plants. Science $143: 339-346$.

Schwarz, J. R. \& Landau, J. V. 1972. Inhibition of cell-free protein synthesis by hydrostatic pressure. - J. Bacteriol. 112: $1222-1227$.

Snedecor, G. W. \& Cochran, W. G. 1956. Statistical Methods. - Iowa State College Press, Ames, Iowa.

Tuve, T. W. \& Anfinsen, C. B. 1960. Preparation and properties of spinach ribonuclease. - J. Biol. Chem. 235. 3437-3441. 